UDC 672

\title{
The influence of nanostructural oxide films on wear-resistance of titanium materials
}

\begin{abstract}
A. M. Petrova, M. B. Shtern
The wearing mechanism of titanium material of the $\mathrm{Ti}-\mathrm{Cr}-\mathrm{TiC}$ composition obtained by different ways of leading chromium and carbon into titanium as separate elements $\mathrm{Cr}$ and $\mathrm{TiC}$ or as a compound $\mathrm{Cr}_{3} \mathrm{C}_{2}$ was investigated. The formation of nanostructural oxide films acting like a solid lubrication at friction on the surface of titanium materials was shown. Defensive properties of the oxide films on the friction surface of $\mathrm{Ti}_{-}-\mathrm{Cr}_{3} \mathrm{C}_{2}$ material are stronger. The structure of such a material consists of small titanium carbide engagings that have a strong connection to titanium-chromium base and work till the abrasion.
\end{abstract}

The study of wearing out and friction of titanium materials containing chromium and carbide of titanium is depicted in papers [1-3]. It is shown the positive influence of alloying material of chromium and solid inclusions of titanium carbide on its wear-resistance.

The paper is aimed at examining the mechanism of wearing for $\mathrm{Ti}-\mathrm{Cr}-\mathrm{TiC}$ materials obtained by different ways of leading chromium and carbon into titanium as separate elements $\mathrm{Cr}$ and $\mathrm{TiC}$ or as a compound $\mathrm{Cr}_{3} \mathrm{C}_{2}$. In the last case chromium carbide interacts with titanium in the process of sintering forming at that the its carbide and alloying titanium base with the chromium.

Examination was carried out on the compositions $\mathrm{Ti}-\mathrm{TiC}, \mathrm{Ti}-\mathrm{Cr}$, $\mathrm{Ti}-\mathrm{Cr}-\mathrm{TiC}, \mathrm{Ti}-\mathrm{Cr}_{3} \mathrm{C}_{2}$ containing an equal amount of input $\mathrm{Ti}, \mathrm{Cr}$ and $\mathrm{C}$ and obtained by pressing and subsequent sintering in vacuum $0,13 \mathrm{~Pa}$ from the mixture of powders of electrolytic titanium of $-180+40 \mu \mathrm{m}$ fraction and $\mathrm{TiC}$, $\mathrm{Cr}, \mathrm{Cr}_{3} \mathrm{C}_{2}$ of $10 \mu \mathrm{m}$ fraction. Density of the materials amounted to $4,3-4,4 \mathrm{~g} / \mathrm{cm}^{3}$.

Tests were realized on the friction machine M-22M (4) working by the scheme shaft-bush, in the air, sliding race of $1 \mathrm{~m} / \mathrm{s}$, graduate increase of loading from 2,3 to $15,0 \mathrm{MPa}$, and for the $\mathrm{Ti}-\mathrm{Cr}_{3} \mathrm{C}_{2}$ material - up to the loading at which a catastrophic wearing out is observed. Hardened steel 45 (HRC 45-50) was used as a rider. Wear-resistance of friction couple was estimated by the wearing intensity of the sample and ride, measurable to $25 \mu \mathrm{m} / \mathrm{km}$. The temperature of friction surface was calculated with the help of chromel-alumel thermocouple at the edge of contact zone for sample and rider. The results of the test are given in the table.

Wearing tests (the table) showed an extreme wearing out of titanium material Ti-TiC while the first loading of $P=25 \mathrm{MPa}$ as well as unsteady character of titanium-chromium alloy wearing and high wear-resistance at all the following loadings for the material, containing $\mathrm{TiC}$ and $\mathrm{Cr}$ conjointly.

The structure, microhardness of friction surface and materials was investigated by cut transversely to friction surface. The X-ray analysis of wearing products of friction couples as well as from the surface of friction was carried out.

(C) A. M. Petrova, M. B. Shtern, 2008 
Wearing out $I$, friction coefficient $\mu$, the tempeture in the friction zone $T$ of the friction couples, titanium material - hardened Steel 45 at $V=1,0 \mathrm{~m} / \mathrm{s}$, at graduated loading

\begin{tabular}{|c|c|c|c|c|c|c|c|c|c|c|c|c|}
\hline \multirow{2}{*}{$\begin{array}{c}P, \\
\mathrm{MPa}\end{array}$} & \multicolumn{3}{|c|}{$\mathrm{Ti}-\mathrm{TiC}$} & \multicolumn{3}{|c|}{$\mathrm{Ti}-\mathrm{Cr}$} & \multicolumn{3}{|c|}{$\mathrm{Ti}-\mathrm{Cr}-\mathrm{TiC}$} & \multicolumn{3}{|c|}{$\mathrm{Ti}-\mathrm{Cr}_{3} \mathrm{C}_{2}$} \\
\hline & $\begin{array}{c}I, \\
\mu \mathrm{m} / \mathrm{km}\end{array}$ & $\mu$ & $\begin{array}{l}T, \\
{ }^{\circ} \mathrm{C}\end{array}$ & $\begin{array}{c}I, \\
\mu \mathrm{m} / \mathrm{km}\end{array}$ & $\mu$ & $\begin{array}{l}T, \\
{ }^{\circ} \mathrm{C}\end{array}$ & $\begin{array}{c}I, \\
\mu \mathrm{m} / \mathrm{km}\end{array}$ & $\mu$ & $\begin{array}{l}T, \\
{ }^{\circ} \mathrm{C}\end{array}$ & $\begin{array}{c}I, \\
\mu \mathrm{m} / \mathrm{km}\end{array}$ & $\mu$ & $\begin{array}{l}T, \\
{ }^{\circ} \mathrm{C}\end{array}$ \\
\hline 2,5 & Cat. & - & - & 330 & 0,15 & 75 & 70 & 0,27 & 80 & $<25$ & 0,32 & 80 \\
\hline 5,0 & & & & 90 & 0,17 & 100 & $<25$ & 0,33 & 190 & $<25$ & 0,35 & 110 \\
\hline 7,5 & & & & 25 & 0,3 & 150 & $<25$ & 0,35 & 230 & $<25$ & 0,32 & 120 \\
\hline 10,0 & & & & 80 & 0,39 & 300 & $<25$ & 0,37 & 250 & $<25$ & 0,34 & 220 \\
\hline 12,5 & & & & 2000 & 0,42 & 380 & $<25$ & 0,37 & 300 & $<25$ & 0,32 & 300 \\
\hline 15,0 & & & & & & & $<25$ & 0,38 & 330 & $<25$ & 0,38 & 330 \\
\hline
\end{tabular}

The X-ray analysis of wearing products of friction couples $\left(\mathrm{Ti}-\mathrm{Cr}_{3} \mathrm{C}_{2}\right)$ hardened steel 45 shows the presence of oxides, hydroxides, nitrides, ferric, titanium, chromium hydrides of the following compounds (in keeping with the decrease of line number at rontgenogram): $\mathrm{Fe}_{3} \mathrm{O}_{4}, \mathrm{Fe}_{2} \mathrm{O}_{3}, \mathrm{FeCr}_{2} \mathrm{O}_{4} ; \mathrm{TiO}_{2} ; \mathrm{TiN}$; $\mathrm{TiH}_{2}, \mathrm{TiC}, \quad \beta . \mathrm{Fe}_{2} \mathrm{O}_{3} \cdot \mathrm{H}_{2} \mathrm{O}, \quad \mathrm{Cr}_{2} \mathrm{O}_{3}, \mathrm{CrO}_{3}, \mathrm{Cr}_{2} \mathrm{~N}$. Higher contents of iron compounds in the wearing products is the evidence of prevailing wearing of steel rider. X-ray analysis of the friction surface of $\mathrm{Ti}-\mathrm{Cr}$ alloy discloses the oxides $\mathrm{Fe}_{3} \mathrm{O}_{4}, \mathrm{Fe}_{2} \mathrm{TiO}_{4}, \mathrm{Cr}_{2} \mathrm{O}_{3}, \mathrm{TiO}_{2}$ and the compound $\mathrm{Fe}_{2} \mathrm{Ti}$. The presence of titanium material of the compound containing iron on the friction surface may be explained by the transition of rider material on conjugate surface with its next interaction with titanium and formation of $\mathrm{Fe}_{2} \mathrm{Ti}$ compound and of compound oxide $\mathrm{Fe}_{2} \mathrm{TiO}_{4}$ of spinel type. Nitrides, oxides, titanium and chromium hydrides are the products of the interaction between titaniumchromium basis of material and air; titanium carbide is present in the wearing products as a result of wearing out of titanium material. Chromium, ferric and titanium oxides formed in the process of friction as well as compound oxide of spinel type participate on the formation of surface wear-resistance nanostructural films; nitrides, hydroxides and carbides bring the elements of abrasive wearing.

The friction surface of Ti-TIC material is uneven and has the areas of deep pits at those places where the titanium carbide inclusions come out on the friction surface, which apparently are painted out. The size of carbide inclusions exceeds significantly the one to be input and comes to $100 \mu \mathrm{m}$. That is a result of coagulation in the process of sintering. There is no strain. Microhardness from the friction surface deep into the material is equal and amounts to 2,4-3,5 $\mathrm{MPa}$. Light parts as a de facto contact between sample and rider are narrow and interrupted.

Plastic strain shows itself within the surface layer of titanium-chromium alloy $\mathrm{Ti}-\mathrm{Cr}$. It is expressed by the crush of base grains which are situated directly within the surface layer as well as by its oblongness along the friction way and by the typical strain lines curve deep into the material. A significant shear strain causes the separation of the thin surface layer of the material which is fixed on the picture as thin light band under which a dark area of the destroyed material may be observed. Microhardness of the strained layer is the same as of the sample's core, amounts 3,2-4,2 MPa that 1,0 MPa higher than 
the titanium in $\mathrm{Ti}-\mathrm{TiC}$ material. The increase of microhardness can be explained by the influence of alloying element of chromium on the microhardness of titanium. The structure of titanium-chromium alloy is single-phase and largegrained. Plastic strain causes the flow of the material and results in enclose of the pores of the sintered sample with the compaction of the material under the friction surface.

At the input of chromium and titanium carbide conjointly into titanium the plastic strain of the surface layer loses significantly its tenseness, the lines of strain are directed to the friction surface at angle of $45^{\circ}$ and are observed in thin surface layer of the deep $\mu \mathrm{m}$. There are some small inclusions of chromium and titanium compounds in the surface layer. The friction surface is unev, although the parts of titanium pits are not as evident as in case of $\mathrm{Ti}-\mathrm{TiC}$ material. Oxide film on the friction surface contains a number of parallel dark tracks appeared as a result of abrasive carbide inclusions.

Some insignificant parts of the material are subjected to plastic strain within the $\mathrm{Ti}-\mathrm{Cr}_{3} \mathrm{C}_{2}$. These parts are situated under the surface layer strengthened by dispersed particles which differr in looks from the bigger inclusions of titanium carbide and are the secondary compounds appeared in the process of friction. The depth of the strengthened layer is $5-7 \mu \mathrm{m}$ and microhardness is 15-20 MPa higher than the core of the sample. The inclusions of TiC in size of $5-10 \mu \mathrm{m}$ at the outlet on the friction surface preserve the strong connection with the metal base of the material and work till the abrasion. The friction surface is even, without any pit-parts of structural components. Therefore, some small inclusions of titanium carbide that are formed within the material have a strong connection to the base and prevent significantly the plastic strain at friction rather that while putting the titanium carbide into the charge. The decrease of plastic strain as well as the wear of the material creates the conditions for the oxygen, hydrogen and nitrogen penetration deep into the material which results in formation of the layer strengthened by titanium oxides, hydrides and nitrides which in their turn make the plain strain of the surface layer go down and increase the wear-resistance of the material.

The friction surface of the material contains wide light bands of the oxide films that are destroyed by the abrasive particles in some places. Microhardness of the friction track grows up to $130-250 \mathrm{MPa}$. It is an evidence of significant strengthening of the titanium material in zones of direct contact between the material and rider.

With the rise of loading to the extreme wearing out that takes place at $P=$ $=30,0 \mathrm{MPa}$ wide light bands disappear from the friction surface of $\mathrm{Ti}-\mathrm{Cr}_{3} \mathrm{C}_{2}$ material and the presence of interchangeable permanent thin light and dark bands which may be an evidence of active destruction of the oxide film that gets milder under the action of upcoming high temperature in the friction zone as well as gets more mobile and speeds away from the friction surface .

Therefore, $\mathrm{Ti}-\mathrm{Cr}, \mathrm{Ti}-\mathrm{Cr}-\mathrm{TiC}, \mathrm{Ti}-\mathrm{Cr}_{3} \mathrm{C}_{2}$ nanostructural oxide films formed at friction of titanium materials perform the function of solid lubricant. Its defensive properties depend on applies loadings, sheer strain of surface layers, size and durability of the connection between carbide titanium inclusions with titanium-chromium basis.

Defensive properties of the oxide films formed at the friction of $\mathrm{Ti}-\mathrm{Cr}_{3} \mathrm{C}_{2}$ material are stronger. The titanium carbide is not put directly into the initial 
charge but is formed in the process of sintering while putting the chromium into the titanium carbide. The structure of such a material contains some small inclusions of titanium carbide that are formed during sintering and that have a strong connection to the titanium-chromium base.

1. Radomysel'skii I. D., Titarenko S. V., Petrova A. M., Polotai V. V. The studying of friction and wearing for the sintered titanium materials // Powder Metallurgy. 1977. - No. 6. - P. 61-66.

2. Petrova A. M., Polotai $V$. $V$. To the wearing out mechanism of titanium-chromium alloys in the air // Abstract of the report on All-Union conf. "Technical control over the tribotechnical characteristics of the friction units", Kishinev. - 1985. P. 116-117.

3. Petrova A. M., Polotai $V . V$. Effect of the chromium contents on the tribotechnical characteristics of titanium-chromium alloys // Powder Metallurgy. — 1987. No. 5. - P. 51-56.

4. Kolesnichenko L. F., Polotai V. V., Zabolotnyi L. V. Methodology of the complete studying of the friction and wearing of the ceramic materials // Ibid. - 1970. No. 3. - P. 61-66. 